\title{
Evaluation of identification techniques for the fish pathogen, Aeromonas hydrophila, from Indonesia
}

\author{
Diah Kusumawaty ${ }^{1,2}$, Adi Pancoro', I. Nyoman P. Aryantha ${ }^{1}$ and Sony Suhandono ${ }^{1 *}$ \\ ${ }^{1}$ School of Life Sciences and Technology, Bandung Institute of Technology, Indonesia. Jl. Ganesha No. 10, Bandung \\ 40132 Indonesia. \\ ${ }^{2}$ Dept. of Biology Education, Indonesia University of Education, Jl. Dr. Setiabudi No 229 Bandung 40154 Indonesia. \\ Email: sony@sith.itb.ac.id
}

Received 30 September 2015; Received in revised form 9 December 2015; Accepted 9 December 2015

\begin{abstract}
Aims: This study evaluated the accuracy of three methods used in the identification of Aeromonas hydrophila, a Gramnegative bacterium found in warm aquatic environments. A. hydrophila samples from Indonesia were tested using (a) SNI 7303, developed by the Indonesian government, (b) the method of Dorsch and (c) the method of Cascón. The results obtained were compared to that of the gold standard method, which used 16S rDNA sequences.

Methodology and results: Based on the Indonesian government standard identification method SNI7303, we identified 56 out of 95 samples as $A$. hydrophila. The samples were then screened using the PCR amplification approach developed by Dorsch and Cascón. Of the 56 samples, only 20 samples were found to be positive by either the Dorsch or Cascón methods. DNA from these 20 samples was amplified using common 16S rDNA primers and the sequences compared with available 16S rDNA sequences from the GenBank. Phylogenetic analyses on the data were performed using Clustal $X$ and MEGA 5 software.

Conclusion, significance and impact of study: Of the 56 samples positively identified as $A$. hydrophila using the BSN method, identity in only five samples were positively confirmed using the16S rDNA method, giving an accuracy of only $8.9 \%$. In this connection, the Dorsch method was $31.3 \%$ accurate while the Cascón method provided $45.5 \%$ correct identification. When all three methods were used in combination, $71.4 \%$ of the samples were correctly identified. The results of the study show that methods used to identify $A$. hydrophila cannot be used with confidence to identify $A$. hydrophila from Indonesia and probably from other tropical regions as well. The genetic diversity of Aeromonas bacteria in Indonesia appears to be considerably higher than that encountered by Dorsch or Cascón. Therefore, there is a need to develop a new simple method to identify $A$. hydrophila from tropical regions.
\end{abstract}

Keywords: Aeromonas hydrophila, identification, phylogenetic, 16S rDNA

\section{INTRODUCTION}

Aeromonas hydrophila is a pathogenic bacterium found in various aquatic environments, such as fish ponds, rivers, lakes, even in sparkling chlorinated drinking water reservoirs. It is pathogenic to shrimps, frogs, and fishes (Martin-Carnahan and Joseph, 2005; EPA, 2006). The infection caused by this bacterium can lead to significant mortality rates within a short period, causing losses to fish and shrimp breeders (Illanchezian et al., 2010; Mangunwardoyo et al., 2010). The disease symptoms vary, but infected fish generally show skin ulcers and haemorrhaging in the skin, gills, and oral cavity (Gardenia et al., 2010).

High mortality in gourami fish occurring over short periods has caused great losses to fish breeders. For example, in Lubuk Pandan, a city in the West Sumatra Province of Indonesia, 47 tons of gourami worth
USD235,000 and 2.7 million juvenile fish worth USD200,000 died in three days (Diraja, 2007 in Eka, 2010). Laboratory experiments have shown that $10^{5}-10^{10}$ $\mathrm{CFU} / \mathrm{mL} A$. hydrophila can kill the fish in only three days after infection (Triyaningsih et al., 2014). Moreover, $A$. hydrophila is frequently associated with human diarrhea. Alberts et al. (1990) found that $12.2 \%$ of toddlers with acute diarrhea in Dhaka, Bangladesh, tested positive for $A$. hydrophila. Hence, a rapid method to determine $A$. hydrophila concentration in fish ponds and to ensure the supply of safe drinking water is urgently needed.

The difficulty in distinguishing between $A$. hydrophila and other species within the Aeromonas genus stems from the complexity of its identifying characters, sometimes varying even within the species (Soler et al., 2004; Ottaviani et al., 2011). Identification using classical 
phenospecific methods is hence error-prone as shown by Beaz-Hidalgo et al. (2010) in the recent Bergey's Manual of Systematic Bacteriology. For example, a positive ADH (arginine dihydrolase) test and hydrolysis of glutamine cannot differentiate between $A$. hydrophila and $A$. sobria. Moreover, conventional methods that do not employ genetic constitution tend to be tedious and complex (Abbott et al., 2003).

The gold standard method in the identification of bacteria involves analysis of $16 \mathrm{~S}$ rDNA. However, this method is dependent on DNA sequencing, facilities for which are not available in many laboratories. Therefore, there is a need to develop alternative practical and accurate identification methods for $A$. hydrophila. A standard biochemical method to identify $A$. hydrophila SNI 7303 (BSN, 2009) has been developed by Indonesian Marine and Fisheries Department. This official protocol is frequently used to detect $A$. hydrophila in Indonesia (Tanjung et al., 2013; Hardi et al., 2014; Tulung et al., 2014).

Other DNA-based methods for the identification of $A$. hydrophila have been reported by Dorsch et al. (1994) and Cascón et al. (1996). Dorsch et al. (1994) designed primers to amplify specific regions of the 16S rDNA of $A$. hydrophila. The $685 \mathrm{bp}$ amplicon that distinguishes $A$. hydrophila from other Aeromonas species has been used for identification of the former by Chu and Lu (2008) and Pandove et al. (2013). Adopting a different approach, Cascón et al. (1996) designed PCR primers from the lipase gene of $A$. hydrophila $\mathrm{H} 3$. This method is rapid and specific in identifying $A$. hydrophila isolated from aquatic environments (Hiney and Smith, 1998; Abdullah et al., 2003; Salimi et al., 2013; Afsari et al., 2014). The PCR product, a 760 bp amplicon, has also been employed by Lee et al. (2000) to identify $A$. hydrophila in diseased fishes in Korea, while Swaminathan et al. (2004) successfully detected four out of nine $A$. hydrophila isolates from fish and water using the method of Cascón et al.

Nevertheless, both the methods of Dorsch et al. and Cascón et al. have not been validated against the gold standard established using complete sequence of $16 \mathrm{~S}$ rDNA (Jiang et al., 2006). This is the first research, to our knowledge, that evaluates the accuracy (sensitivity) of the methods of Dorsch et al. (1994) and Cascón et al. (1996) for the identification of $A$. hydrophila from a population of Aeromonas in Indonesia.

\section{MATERIALS AND METHODS}

\section{The isolation of Aeromonas hydrophila}

In order to sample Aeromonas species from diverse environments, we collected bacteria from different sources. Bacteria samples were isolated from the intestines of healthy and diseased fish obtained from Balai Riset Perikanan Budidaya Air Tawar (Research Institute of Freshwater Aquaculture) Sempur Bogor and Sukabumi. Other bacteria samples were isolated from fish ponds in West Java (Indonesia) cities, including
Tasikmalaya, Garut, Bandung, Indramayu, and Sukabumi. When initially cultured on Rimler-Shotts medium + novobiocin, the colonies of suspected $A$. hydrophila appeared white with a bright yellow zone in the middle of the colony. The isolates were sub-cultured on Trypticase Soy Agar (TSA) slants and incubated at $28^{\circ} \mathrm{C}$ for $24 \mathrm{~h}$ before being subjected to an array of tests and analyses, including Gram staining, motility test, oxidase test, blood agar test, oxidative-fermentative test and Rimler-Shotts+novobiocin test (Rimler and Shotts, 1973; BSN, 2009). During this procedure, the morphology of the isolate under investigation was compared with that of the reference $A$. hydrophila ATCC 7966 obtained from Microbiologic Co.

\section{Bacterial DNA isolation and analysis}

To isolate bacterial DNA, the bacterial colony was resuspended in one milliliter PBS (Phosphate Buffer Saline) and homogenized using a vortex mixer. The tube was centrifuged at $1680 \mathrm{rcf}$ for $3 \mathrm{~min}$. The supernatant was discarded and the pellet was mixed with $100 \mu \mathrm{L} 1 \times \mathrm{TE} \mathrm{pH}$ 8.0 , and homogenized using a vortex mixer. The sample was incubated in boiling water for $10 \mathrm{~min}$, and then centrifuged for $1 \mathrm{~min}$ at $1680 \mathrm{rcf}$. A total of $100 \mu \mathrm{L}$ of the lysate was transferred to a new $1.5 \mathrm{~mL}$ sterile tube and dissolved in $900 \mu \mathrm{L}$ cold $1 \times$ TE. Several sample aliquots of $200 \mu \mathrm{L}$ were stored at $-20^{\circ} \mathrm{C}$ for use as template DNA in conjunction with specific primers designed by Dorsch et al. (1994), Cascón et al. (1996), and Jiang et al. (2006) for PCR. Following electrophoresis on $1 \%$ agarose gel, DNA sequencing was performed at Macrogen Korea. The PCR solution mix and primers used are shown in Table 1. The sequencing results were subjected to BLAST analysis, with sequences aligned and compared with the other Aeromonas 16S rDNA from the GenBank database NCBI (National Center for Biotechnology Information;http://www.ncbi.nml.nih.gov/BLAST/Blast.cgi). Eleven sequences of Aeromonas 16S rDNA were chosen from BLAST analysis for comparison with 16S rDNA sequence from 20 samples which were identified as positive using the Cascón and Dorch methods. The comparison was made using phylogenetic analysis based on program of Clustal $X$ and MEGA 5 software (Tamura et al., 2011). To construct a phylogenetic tree, we used three 16S rDNA sequences from $A$. hydrophila as references, viz. (1) $16 \mathrm{~S}$ rDNA generated from living $A$. hydrophila (ATCC 7966) from Microbiologic Co, (2) $16 S$ rDNA sequence of $A$. hydrophila (ATCC 7966) available at GenBank NCBI, and (3) 16S rDNA sequence of $A$. hydrophila (ATCC 4910) available at GenBank NCBI. Other reference $16 \mathrm{~S}$ rDNA sequences were later identified from the NCBI database based on the BLAST results. We also used the 16S rDNA sequence of Tolumonas auensis strain DSM 9187 from GenBank as an out-group. Tolumonas auensis is a member of the Aeromonad group, but is of a different genus from Aeromonas. 
Table 1: Primer sequences and amplification programs used.

\begin{tabular}{|c|c|c|c|}
\hline & $\begin{array}{l}\text { Dorsch } \\
\text { et al., } 1994\end{array}$ & $\begin{array}{l}\text { Cascón } \\
\text { et al., } 1996\end{array}$ & $\begin{array}{l}\text { Jiang } \\
\text { et al., } 2006 \\
\text { (16S rDNA) }\end{array}$ \\
\hline Size & $685 \mathrm{bp}$ & $760 \mathrm{bp}$ & $\pm 1450 \mathrm{bp}$ \\
\hline F 5'-3' & $\begin{array}{l}\text { GAAAGGTTGATGCCTAATA } \\
\text { CGTA }\end{array}$ & $\begin{array}{l}\text { AACCTGGTTCCGCTCAAGCCG } \\
\text { TTG }\end{array}$ & $\begin{array}{l}\text { AGAGTTTGATCCTGGCT } \\
\text { CAG }\end{array}$ \\
\hline R 5'-3' & $\begin{array}{l}\text { CGTGCTGGCAACAAAGGAC } \\
\text { AG }\end{array}$ & $\begin{array}{l}\text { TTGCCTCGCCTCGGCCCAGCA } \\
\text { GCT }\end{array}$ & $\begin{array}{l}\text { GGTTACCTTGTTACGAC } \\
\text { TT }\end{array}$ \\
\hline $\begin{array}{l}\text { Initial } \\
\text { denaturation }\end{array}$ & $95^{\circ} \mathrm{C}, 5 \mathrm{~min}$ & $95^{\circ} \mathrm{C}, 5 \mathrm{~min}$ & $95^{\circ} \mathrm{C}, 5 \mathrm{~min}$ \\
\hline Cycle & 28 & 28 & 28 \\
\hline Denaturation & $95^{\circ} \mathrm{C}, 15 \mathrm{sec}$ & $95^{\circ} \mathrm{C}, 15 \mathrm{sec}$ & $95^{\circ} \mathrm{C}, 30 \mathrm{sec}$ \\
\hline Annealing & $57^{\circ} \mathrm{C}, 15 \mathrm{sec}$ & $65^{\circ} \mathrm{C}, 15 \mathrm{sec}$ & $54^{\circ} \mathrm{C}, 30 \mathrm{sec}$ \\
\hline Extension & $72^{\circ} \mathrm{C}, 30 \mathrm{sec}$ & $72^{\circ} \mathrm{C}, 30 \mathrm{sec}$ & $72^{\circ} \mathrm{C}, 90 \mathrm{sec}$ \\
\hline Final Extension & $72^{\circ} \mathrm{C}, 5 \mathrm{~min}$ & $72^{\circ} \mathrm{C}, 5 \mathrm{~min}$ & $72^{\circ} \mathrm{C}, 5 \mathrm{~min}$ \\
\hline Enzyme & $\begin{array}{l}2 \times \text { Green Kappa } 2 \mathrm{G} \text { fast ready } \\
\mathrm{mix}\end{array}$ & $\begin{array}{l}\text { 2x Green Kappa } 2 \mathrm{G} \text { fast ready } \\
\text { mix }\end{array}$ & $\begin{array}{l}2 \times \text { Green GoTaq ready } \\
\text { mix, Promega }\end{array}$ \\
\hline
\end{tabular}

\section{RESULTS AND DISCUSSION}

\section{Aeromonas hydrophila isolation}

Using Rimler and Shotts (1973) selective medium, we obtained 95 bright yellow color isolates with white edges, consistent with the characteristics of $A$. hydrophila. Of the 95 isolates, further screening using the SNI 7303 method (BSN, 2009) brought the number down to 56. The isolates were further screened using the methods of Dorsch et al. (1994) and Cascón et al. (1996).

\section{Bacterial DNA isolation and Identification}

DNA amplification using the Dorsch method produced amplicons similar in size to those of the control sample $A$. hydrophila ATCC 7966. On the other hand, the Cascón method produced amplicons of varying sizes, some of them similar to the amplicon size produced by the control isolate. With respect to $A$. hydrophila identification, the Cascón and Dorsch methods produced inconsistent results. For example, in an examination of the control isolate (A. hydrophila ATCC 7966) and six test isolates, all of the test isolates (SfB, SfN, SfL, SfM, SfP, and FpT9) produced 685 bp amplicons using Dorsch method. However, using the Cascón method, only two isolates (SfB and FpT9) produced amplicons similar in size to the control amplicon. The other four samples (SfN, SfL, SfM, $\mathrm{SfP}$ ) either generated amplicons of different sizes, or no relevant product was produced altogether (Figure 1).

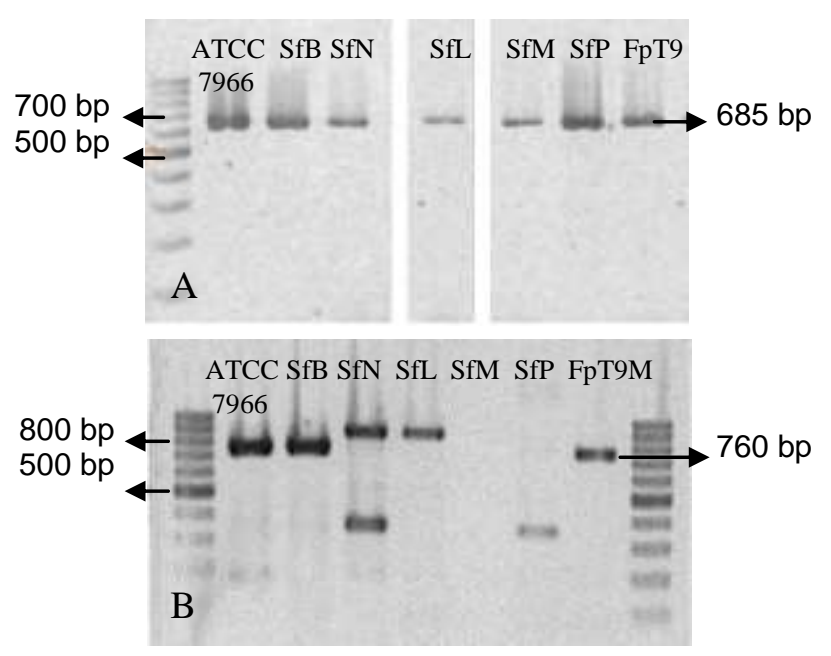

Figure 1: DNA amplification using specific primers for $A$. hydrophila. A, Method of Dorsch et al. (1994) B, Method of Cascón et al. (1996). Amplicons from the reference culture ( $A$. hydrophila ATCC 7966) and six test isolates (SfB, SFN, SfL, Sf, SfP, FpT9). M, 100 bp ladder.

Of the 56 isolates selected using SNI 7303 (BSN, 2009), only 17 samples were positively identified as $A$. hydrophila using the Dorsch method, and only 11 samples were similarly identified based on the Cascón method. Seven samples were consistently positive for both methods and 20 samples were positive either for the Cascón or the Dorch method (Table 2). 
Table 2: Screening for $A$. hydrophila in 20 bacterial isolates based on the BSN method, the Dorsch method, the Cascón method, and the Jiang method 16S rDNA-based phylogenetic analysis.

\begin{tabular}{|c|c|c|c|c|}
\hline Name of Isolate & $\begin{array}{l}\text { SNI 7303 } \\
(2009)\end{array}$ & $\begin{array}{l}\text { Dorsch et al., } \\
\text { (1994) }\end{array}$ & $\begin{array}{l}\text { Cascón et al., } \\
\text { (1996) }\end{array}$ & $\begin{array}{l}\text { 16S rDNA } \\
\text { Jiang et al., (2006) }\end{array}$ \\
\hline ATCC 7966 (Control) & A. hydrophila & A. hydrophila & A. hydrophila & A. hydrophila \\
\hline 1.SfB & A. hydrophila & A. hydrophila & A. hydrophila & A. hydrophila \\
\hline 2. $\mathrm{FpT}_{9}$ & A. hydrophila & A. hydrophila & A. hydrophila & A. hydrophila \\
\hline 3. $\mathrm{FpB}_{1}$ & A. hydrophila & A. hydrophila & A. hydrophila & A. hydrophila \\
\hline 4. $\mathrm{HfM}_{1}$ & A. hydrophila & A. hydrophila & A. hydrophila & A. hydrophila \\
\hline 5. $\mathrm{HfNp}$ & A. hydrophila & A. hydrophila & A. hydrophila & A. hydrophila \\
\hline 6.SfP & A. hydrophila & A. hydrophila & unidentified & A. media \\
\hline 7.FplS 1 & A. hydrophila & unidentified & A. hydrophila & Aeromonas sp. \\
\hline 8.FplS 3 & A. hydrophila & unidentified & A. hydrophila & Aeromonas sp. \\
\hline 9.FplA & A. hydrophila & A. hydrophila & unidentified & A. taiwanensis \\
\hline 10.FpC & A. hydrophila & A. hydrophila & A. hydrophila & Aeromonas sp. \\
\hline 11.HfLp & A. hydrophila & A. hydrophila & unidentified & Aeromonas sp. \\
\hline 12. $\mathrm{HfL}_{1}$ & A. hydrophila & unidentified & A. hydrophila & A. veronii \\
\hline 13. $\mathrm{HfL}_{2}$ & A. hydrophila & A. hydrophila & unidentified & Aeromonas sp. \\
\hline 14.FpG & A. hydrophila & A. hydrophila & unidentified & A. jandaei \\
\hline 15.HfTp & A. hydrophila & A. hydrophila & A. hydrophila & A. jandaei \\
\hline 16.SfM & A. hydrophila & A. hydrophila & unidentified & A. veronii \\
\hline 17.SfL & A. hydrophila & A. hydrophila & unidentified & A. veronii \\
\hline 18.SfN & A. hydrophila & A. hydrophila & unidentified & A. veronii \\
\hline 19. HfMn & A. hydrophila & A. hydrophila & unidentified & A. veronii \\
\hline 20. $\mathrm{FpT}_{1}$ & A. hydrophila & unidentified & A. hydrophila & A. veronii \\
\hline 21-56 not sequenced & & & & \\
\hline
\end{tabular}

Other than the control isolate $A$. hydrophila ATCC 7966, the isolates that were strongly identified as $A$. hydrophila were the isolates $\mathrm{SfB}, \mathrm{HfM}_{1}, \mathrm{HfNp}, \mathrm{FpT}_{1}, \mathrm{FpC}$, $\mathrm{FpT}_{9}$. and $\mathrm{FpB}_{1}$. To assess both the Dorsch and Cascón methods, we made a comparison with $16 \mathrm{~S}$ rDNA sequences from all of the 20 samples that were tested positive to either method. We also included isolates that did not produce amplicons using both the Dorsch and Cascón methods. The phylogenetic analysis also included 12 different Aeromonas species from GenBank and one species $T$. auensis strain DSM 9187 as an out-group. The phylogenetic tree was constructed based on multiple alignments of the 16S rDNA regions, using the NeighborJoining method. The result in the form of a phylogenetic tree is shown in Figure 2.

Based on this phylogenetic tree, the species of Aeromonas are very closely related, showing between $96-$ $99 \%$ identity among the tested isolates (Figure 2). The result of this research is consistent with the work of
Martinez-Murcia et al. (1992) where an analysis based on 16S rDNA reached $98-100 \%$ similarity in identity among species of Aeromonas. It was still difficult to distinguish between the minute differences in genotypes (MartinezMurcia et al., 1992; Martinez-Murcia et al., 2005).

Based on the 16S rDNA of 20 samples, there were five other samples that could not be identified as a distinct Aeromonas species. The phylogenetic analysis produced two major groups. However, five sub groups were discernible on closer examination. The first group consisted of three sub groups, where the first sub group included $A$. hydrophila, the second sub group included $A$. media, while the third sub group was very difficult to distinguish because it consisted of more than one species. One sample from the third sub group was very similar to A. taiwanessis. The second group consisted of two sub groups, while the fourth sub group comprised only $A$. jandaei, and the fifth sub group comprised only $A$. veronii. This phylogenetic division was very close to the 


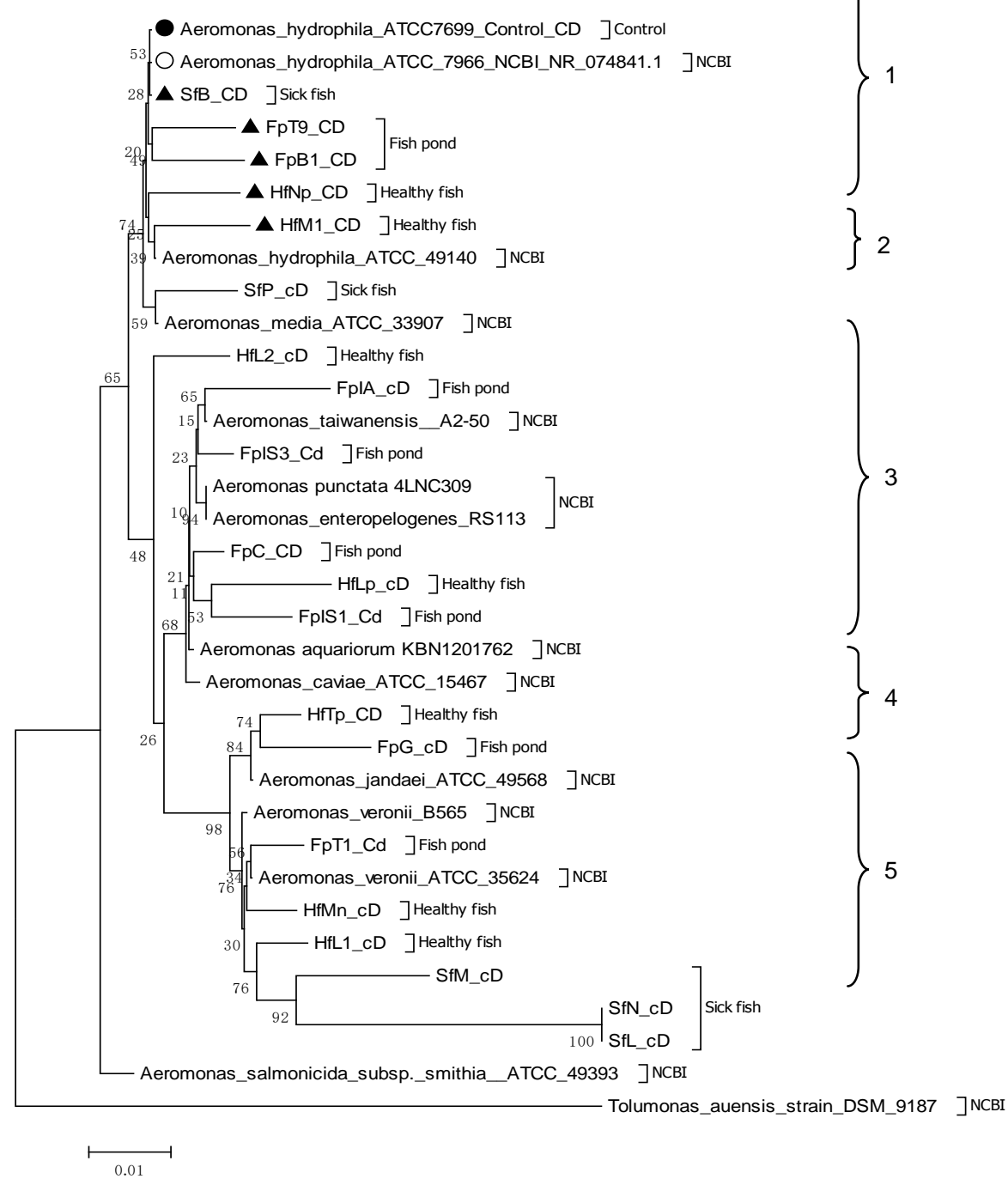

Figure 2: The Neighbor-Joining Phylogenetic Tree constructed using the 16S rDNA sequences from one control isolate, 20 test sample isolates, 12 sequences of Aeromonas sp. as references, and one non-Aeromonas sp. T. auensis strain ATCC DSM 9187 as the out-group. The values at the branches show the Bootstrap 5000 times; $16 \mathrm{~S}$ rDNA generated from living $A$. hydrophila (ATCC 7966) from Microbiologic Co; O, 165 rDNA sequence of $A$. hydrophila (ATCC 7966) available at GenBank NCBI; $\boldsymbol{\Delta}$, the sample isolates that belong to $A$. hydrophila group. $\mathrm{CD},+\mathrm{Cascón} /+\mathrm{Dorsch}$; $\mathrm{CD}$, -Cascón/+Dorsch; Cd, +Cascón/-Dorsch and cd, -Cascón/-Dorsch.

phylogenetic structure of Martinez-Murcia et al. (1992). In this study, we identified at least five species of Aeromonas in our collection, viz. A. hydrophila, A. media, A. taiwanensis, $A$. jandaei and $A$. veronii (Table 2).

Based on Table 2 and the phylogenetic tree in Figure 2 , five isolates which were positively identified using $16 \mathrm{~S}$ rDNA method as $A$. hydrophila were also assigned the same identity using the BSN, Cascón and Dorsch methods. The isolates, $\mathrm{SfB}, \mathrm{FpT}_{9}, \mathrm{FpB}_{1}, \mathrm{HfNp}$ and $\mathrm{HfM}_{1}$ (Table 2), were in the same group as the three 16S rDNA sequences of $A$. hydrophila, and it could therefore be concluded that the five isolates were $A$. hydrophila.
There were 15 other isolates that were not confirmed as $A$. hydrophila. Of these, nine isolates that were identified as $A$. hydrophila using both the BSN and Dorcsh methods were designated by 16S rDNA analysis as Aeromonas sp., (HfLp, $\mathrm{HfL}_{2}$ ), A. veronii (SfL, SfN, SfM, $\mathrm{HfMn}$, A. taiwanensis (FplA), A. jandaei (FpG), and $A$. media (SfP). Four isolates that tested positive for $A$. hydrophila using both BSN and Cascón methods were reassigned as $A$. veronii $\left(\mathrm{FpT}_{1}, \mathrm{HfL}_{1}\right)$ and two isolates of Aeromonas sp. (FplS ${ }_{1}, \mathrm{FpIS}_{3}$ ) by $16 \mathrm{~S}$ rDNA analysis. Finally, two isolates that were positively identified using all three methods were re-classified as $A$. jandaei (HfTp) and Aeromonas sp. (FpC). 
The results from this study showed that there was no distinct division between species of Aeromonas found in healthy fish and diseased fish. For example, $A$. hydrophila and $A$. veronii were found in both healthy fish and diseased fish. Aeromonas media was only found in a diseased fish in this study, but this was the only time the species was encountered in the 95 original samples. Two other species, $A$. taiwanensis and $A$. jandaei, were found in healthy fish and in pond water. According to Kompanets et al. (1992) and Molinari et al. (2003), A. hydrophila can thrive in healthy fish. The virulence of this species is attributed to virulence genes such as cytotoxic aerolysin (aerA), enterotoxin (act), lipase (lip), cytotoxic enterotoxins (ast,alt), glycerol phospholipid cholesterol acyltransferase (gcat), DNases (exu), elastase (ahyB), serine protease (ser), ADP ribosyltransferase (aexT), and the structural gene flagellin (fla) (Nawaz et al., 2010; Puthucheary et al., 2012).

From Table 2, a test using the SNI 7303 protocol (BSN, 2009) would yield 56 positive results, but with only five samples also testing positive with the 16S rDNA method, thereby giving an accuracy of only $8.9 \%$. Of the 16 samples positively identified using the Dorsch method, only five samples matched positive readings in the $16 \mathrm{~S}$ rDNA method (31.3\% accuracy). Of the eleven samples positively identified using the Cascón method, only five samples were corroborated by test results using the $16 \mathrm{~S}$ rDNA method (45.5\% accuracy). Of the seven samples that were tested positive using all of the three methods, only five samples were validated as positive using the 16 S rDNA method, giving an accuracy of $71.4 \%$.

The Cascón method produces positive results in species other than $A$. hydrophila, and so in regard, it is lacking in test specificity. Ottaviani et al. (2011) reports that the Cascón method also tests positive for other Aeromonas species such as $A$. popoffii, and $A$. bestarium. Further analysis of the lipase DNA sequences might provide a clearer picture of the phylogeny of Aeromonas sp. The Dorsch method is similarly lacking in test specificity in that, from a BLAST analysis, the Dorsch primers would be expected to recognize 16S rDNA sequences of species such as $A$. media, $A$. encheleia, $A$. veronii, A. salmonicida, and $A$. bestiarum. This explains why test results using Dorsch primer are not always accurate. While the Cascón primers are very specific for the $A$. hydrophila lipase, there are approximately 100 Aeromonas lipase sequences in the Genebank database (accessed 30 October 2015), and hence the Cascón primers might amplify lipase genes from Aeromonas species other $A$. hydrophila. This could explain the observation of multiple band sizes of the PCR products in our study (Figure 1).

\section{CONCLUSION}

The results from this research show that identification of Aeromonas to the species level is very difficult because they are very closely related. Very definitive identification cannot be made using biochemical tests such as the BSN method, or PCR-based tests like the Cascón method or the Dorsch method only. Accuracy of the BSN methods was $8.9 \%$, and this figure refers only to positive SNI 7303 (BSN, 2009) test results that were confirmed by the $16 \mathrm{~S}$ rDNA approach. It does not take into account the possibility that true $A$. hydrophila among the original 95 samples collected might have been wrongly tested negative in the first screening. The accuracy of the Dorsch and Cascón methods were $31.3 \%$ and $45.5 \%$ respectively when compared against the gold standard procedure based on 16S rDNA (Jiang et al., 2006). Even when all the three methods were used together, the accuracy was only $71.4 \%$. The three common methods used to identify $A$. hydrophila are not suitable for the identification of $A$. hydrophila with confidence in Indonesia and probably in other tropical countries too. Hence, there is a need to develop a new simple method for this purpose. On the other hand, A. hydrophila can be found in healthy and diseased fish. This indicates that the $A$. hydrophila consist of at least two strains, one strain can be pathogenic and the other may not pathogenic. Instead of developing identification method for $A$. hydrophila is probably more useful to identify pathogenic Aeromonas species.

\section{ACKNOWLEDGEMENTS}

The authors would like to extend their gratitude to DIKTI (Directorate General of Higher Education Indonesia) Program of Beasiswa Pendidikan Pascasarjana Dalam Negeri (BPP-DN) Scholarship and BNOPTN UPI (Indonesia University of Education) 2013 for funding part of this research. Special thanks to Topik Hidayat and Astri Rinanti Nugroho for discussion.

\section{REFERENCES}

Abbott, S. L., Cheung, W. K. W. and Janda, J. M., (2003). The genus Aeromonas: Biochemical characteristics, a typical reactions, and phenotypic identification schemes. Journal of Clinical Microbiology 41(6), 2348-2357.

Abdullah, A. I., Hart, C. A. and Winstanley, C. (2003). Molecular characterization and distribution of virulence-associated genes amongst Aeromonas isolates from Libya. Journal of Applied Microbiology, 95(5), 1001-1007.

Afsari, N., Naghavi, N. S. and Nazari, A. (2014). Detection of human pathogenic Gram-negative bacteria from ornamental goldfish according to gene sequence alignment. Journal of Biological Sciences 14(4), 332-335.

Albert, M. J., Ansaruzzaman, M., Talukder, K. A., Chopra, A. K., Kuhn, I., Rahman, M., Faruque, A. S. G., M. Islam, S., Sack, R. B. and Mollby, R. (2000). Prevalence of enterotoxin genes in Aeromonas spp. isolated from children with diarrhea, healthy controls, and the environment. Journal of Clinical Microbiology 38(10), 3785-3790.

Badan Standarisasi Nasional (BSN). (2009). Aeromonas hyrdophila identification method with 
biochemical. SNI 7303, 1-9.

Beaz-Hidalgo, R., Alperi, A., Buján, N., Romalde, J. L. and Figueras, M. J. (2010). Comparison of phenotypical and genetic identification of Aeromonas strains isolated from diseased fish. Systematic and Applied Microbiology 33, 149-153.

Cascón, A., Anguita, J., Hernanz, C., Sanchez, M., Fernandez, M. and Naharro, G. (1996). Identification of Aeromonas hydrophila hybridization group 1 by PCR assays. Applied and Environmental Microbiology 62(4), 1167-1170.

Chu, W. H. and Lu, C. P. (2008). In vivo fish models for visualizing Aeromonas hydrophila invasion pathway using GFP as a biomarker. Aquaculture 277(3-4), 152155.

Dorsch, M., Ashbolt, N. J., Cox, T. and Goodman, A. E. (1994). Rapid identification of Aeromonas species using 16S rDNA targeted oligonucleotide primers: A molecular approach based on screening of environmental isolates. Journal of Applied Bacteriology 77, 722-726.

Eka, G. S. P. (2010). Characteristics microsatellite genomic in Osphronemus gouramy. B. Sc. Thesis. Department of Biology Indonesia University of Education.

EPA Office of Water. (2006). Aeromonas: Human Health Criteria Document. Health and ecological criteria division office of science and technology office of water U. S. Environmental Protection Agency Washington.

Gardenia, L., Koesharyani, L., Supriyadi, H. and Mufidah, T. (2010). Applications detection of Aeromonas hydrophila aerolisin producers using Polymerase Chain Reaction (PCR). Proceedings of the Aquaculture Technology Innovation forum, Indonesia. pp. 877-883.

Hardi, E. H., Saptiani, G. and Lustiastuti, A. M. (2014). Characterization of extracelullar proteins produced different conditions. Proceeding of International Conference of Aquaculture Indonesia, Bandung Indonesia. pp. 81-85.

Hiney, M. P. and Smith, P. R. (1998). Validation of Polymerase Chain Reaction-based techniques for proxy detection of bacterial fish pathogens: Framework, problems and possible solutions for environmental applications. Aquaculture 162(1-2), 4168.

Illanchezian, S., Jayaraman, S. K., Manoharan, M. S. and Valsalam, S. (2010). Virulence and cytotoxicity of seafood borne Aeromonas hydrophila. Brazilian Journal of Microbiology 41, 978-983.

Jiang, H., Dong, H., Zhang, G., Yu, B., Chapman, L. R., Fields, M. W. (2006). Microbial diversity in water and sediment of Lake Chaka, an Athalassohaline Lake in Northwestern China. Applied and Environmental Microbiology 72(6), 3832-3845.

Kompanets, E. V., Isaeva, N. M. and Balakhnin, I. A. (1992). Bacteria of genus Aeromonas and their role in aquaculture. Mikrobiologicheskiĭ zhurnal 54(4), 89-99.
Lee, S., Kim, S., Oh, J. and Lee, Y. (2000). Characterization of Aeromonas hydrophila isolated from rainbow trouts in Korea. The Journal of Microbiology 38(1), 1-7.

Mangunwardoyo, W., Ismayasari, R. and Riani, E. (2010). Test pathogenicity and virulence of Aeromonas hydrophila Stanier on tilapia (Oreochromis niloticus Lin.) through the Koch's postulates. Jurnal Riset Akuakultur 5, 245-255.

Martin-Carnahan, A. and Joseph, S. W. (2005). Order XII. Aeromonadales ord. nov. In: Bergey's Manual of Systematic Bacteriology. Brenner, D. J., Krieg, N. R., Staley, J. T. and Garrity, G. M. (eds.). Spinger, New York. pp. 556.

Martinez-Murcia, A. J., Benlloch, S. and Collins, M. D. (1992). Phylogenetic interrelationships of members of the genera Aeromonas and Plesiomonas as determined by 16S Ribosomal DNA sequencing: Lack of congruence with results of DNA-DNA hybridizations. International Journal of Systematic Bacteriology 412-421.

Martinez-Murcia, A. J., Soler, L., Saavedra, M. J., Chacon, M. R., Guarro, J., Stackebrandt, E. and Figueras, M. J. (2005). Phenotypic, genotypic, and phylogenetic discrepancies to differentiate Aeromonas salmonicida from Aeromonas bestiarum. International Microbiology 8, 259-269.

Molinari, L. M., Scoaris, D. O., Pedroso, R. B., Bittencourt, N. L. D., Nakamura, C. V., Nakamura, T. U., Filho, B. A. A. and Filho, B. P. D. (2003). Bacterial microflora in the gastrointestinal tract of Nile tilapia, Oreochromis niloticus, cultured in a semiintensive system. Maringá 25(2), 267-271.

Nawaz, M., Khan, S. A., Khan, A. A., Sung, K., Tran, Q., Kerdahi, K. and Steele, R. (2010). Detection and characterization of virulence genes and integrons in Aeromonas veronii isolated from Catfish. Food Microbiology 27(3), 327-331.

Ottaviani, D., Parlani C., Cittero B., Massini L., Leoni F., Canonico C., Sabatini L., Bruscolini F. and Pianetti A. (2011). Putative virulence properties of Aeromonas strains isolated from food, environmental and clinical sources in Italy: A comparative study. International Journal of Food Microbiology 144, 538545.

Pandove, G., Sahota, P., Vikal, Y. and Kaur, B. (2013). Multiplex PCR water testing kit for rapid, economic and simultaneous detection of Escherichia coli, Yersinia enterocolitica and Aeromonas hydrophila from drinking water. Current Science 104(3), 352-358.

Puthucheary, S. D., Puah, S. M. and Chua, K. H. (2012). Molecular characterization of clinical isolates of Aeromonas species from Malaysia. PloS One 7 (2), 1-7.

Rimler, R. and Shotts, E. B. (1973). Medium for the isolation of Aeromonas hydrophila. College of Veterinary Medicine. American Society for Microbiology, USA. 26, 4.

Soler, L., Yanez, M. A., Chacon, M. R., AguileraArreola, M. G., Catalan, V., Figueras M. J. and 
Martinez-Murcia A. J. (2004). Phylogenetic analysis of the genus Aeromonas based on two housekeeping genes. International Journal of Systematic and Evolutionary Microbiology 54, 1511-1519.

Salimi, S. N., Naghavi, N. S. and Karbasizadeh, V. (2013). Propolis, royal jelly and pollen from beehive have antibacterial effect on aquatic pathogenic bacterial isolates. International Journal of Molecular and Clinical Microbiology 1, 218-224.

Swaminathan, T. R., Rathore, G., Abidi, R. and Kapoor, D. (2004). Detection of Aeromonas hydrophila by polymerase chain reaction. Indian Journal of Fisheries 51(2), 251-254.

Tanjung, L. R., Sadi, N. H., Maghfiroh, M., Dina, R. and Said, D. (2013). Diversity of Aeromonas bacteria from Jatiluhur reservoir floating net cages West Java, and fish ponds in Lombok and Sumbawa Islands. Limnotek 20(1), 100-110.

Tamura K., Peterson D., Peterson N., Stecher G., Nei M. and Kumar S. (2011). MEGA5: Molecular evolutionary genetics analysis using maximum likelihood, evolutionary distance, and maximum parsimony methods. Molecular Biology and Evolution 28, 2731-2739.

Triyaningsih, Sarjito and Prayitno, S. B. (2014). Pathogenicity Aeromonas hydrophila isolated from catfish (Clarias gariepinus) from Boyolali. Journal of Aquaculture Management and Technology 3(2), 1117.

Tulung, J. V., Sinjai, H. and Buyung, C. A. L. D. (2014). Identification of common carp Aeromonas hydrophila in the village district Tatelu Dimembe North Minahasa district. Buletin Sariputra 1(1), 46-50. 